\title{
SHARE VALUE DIFFERENCES PT. KIMIA FARMA TBK TOWARDS THE ACQUISITION OF SHARE EVENTS IN PT. PHAPROS TBK
}

\author{
Revi Candra ${ }^{1)}$, Elmiliyani Wahyuni $\mathbf{S}^{2}$, Nailatul Hanifah ${ }^{3)}$ \\ Faculty of Economics and Islamic Business Batusangkar State Islamic Institute ${ }^{1,2,3}$, West Sumatra

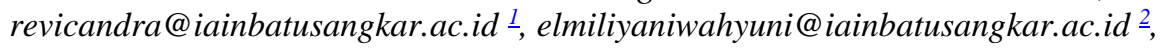 \\ Nailatulhanifah114@gmail.com ${ }^{3}$
}

\begin{abstract}
This study aims to determine whether there is a difference in the value of the shares of PT. Kimia Farma Tbk. after the acquisition of PT. Phapros Tbk. The data used is the value of shares consisting of book value, market value, and the intrinsic value of shares of PT. Kimia Farma Tbk, which was taken ten months before the acquisition of PT. Phapros Tbk. by PT Kimia Farma Tbk. This study is a comparative study with a quantitative descriptive approach, data analysis using the Wilcoxon signed-rank test. The results of this study indicate that the book value of PT. Kimia Farma Tbk. which has a significant difference before and after the acquisition, while the indicators of the stock market value and the intrinsic value of PT. Kimia Farma Tbk. does not have a significant difference before and after the acquisition event.
\end{abstract}

Keywords: Acquisition; Book Value; Market Value; Intrinsic Value

*Corresponding author:

Email: revicandra@iainbatusangkar.ac.id

DOI: https://doi.org/10.33369/j.akuntansi.11.3.247-258

\section{INTRODUCTION}

Shares are certificate sheets that prove a person's ownership of a company that conducts a public offering (go public), and shareholders have the right to income and company assets. Shares can also be interpreted as proof of ownership of a company in a certain nominal or percentage. Shares are the number of units of cooperative capital that the same amount can be rotated in various ways of trading. The price can change at any time depending on the profits and losses or the company's performance (Yuliana, 2010).

Stock is an indicator in determining the value of the company in the capital market. An increase in stock prices is identical to an increase in the prosperity of shareholders, and an increase in share prices is identical to an increase in firm value (Fuad \& Dkk, 2006). There are three types of value known in stock valuation: book value, market value, and intrinsic value of shares (Hartono, 2010).

Internal and external factors influence the determination of stock prices in a period. Internal factors include announcements about marketing, production, sales, funding announcements, the board of directors, announcements of takeovers, announcements of investment, announcements of employment, and announcements of financial statements. External factors that affect stock prices include issues from abroad, legal and government announcements, political turmoil, and announcements of the securities industry (Zulfikar, 2016).

The announcement of the takeover became the most dominant factor in determining the share price. The takeover will affect the company's operational activities, financial performance, and both those who carry out the takeover or those who are taken over. The announcement of the acquisition is essential information in the industry because this activity is a merger of the strengths of two companies. The company will transfer technology, information, and expertise to improve the company's performance. The company is expected to win market competition through this strategy (Liliana et al., 2016). 
The acquisition of a company is carried out by buying the company's majority shares (controlling shares) so that the acquirer has the right to become the controlling shareholder. The general purpose of an acquisition is to increase the wealth of shareholders or owners, with the hope of providing prosperity for shareholders as indicated in the returns that investors will receive for the better after the merger (Liliana et al., 2016).

The main problems in every Merger and acquisition transaction, including; 1) whether the transaction will create value for the shareholders of the acquiring company. 2) Does the stock market react positively to transactions in the short term and, more importantly, does the acquirer's stock outperform in the long run (Hazelkorn et al., 2004).

(Hazelkorn et al., 2004) the study found that mergers and acquisitions activities can play an essential role in creating the acquiring firm's value. (As'ari et al., 2019) the results of the study show that the acquisition has a positive effect on Return on 86 Assets (ROA). (Shleifer \& Vishny, 2003)developed a model that predicts that acquisition activity is driven by managers who take excessive market advantage of their firms.

PT. Kimia Farma Tbk. has signed a conditional share sale and purchase with PT. Phapros Tbk. on February 13, 2019. PT. Kimia Farma Tbk. Buy shares of PT. Phapros Tbk. as many as 476,901,860 shares, which is 56.77\% shares. On March 27, 2019, PT. Kimia Farma Tbk. has officially acquired PT. Phapros Tbk. with an acquisition value of Rp. 1.36 Trillion. At the time of acquiring the share price of PT. Kimia Farma Tbk. is Rp. 3,560.

Table 1. Stock Price Movement of PT. Kimia Farma Tbk. Before and After Acquisition

\begin{tabular}{lccc}
\hline $\begin{array}{l}\text { Before acquisition } \\
\text { Share }\end{array}$ & price & $\begin{array}{c}\text { After acquisition } \\
\text { Share }\end{array}$ & price \\
\hline May 2018 & 2,540 & April 2019 & 3,000 \\
\hline June 2018 & 2,360 & May 2019 & 3,390 \\
\hline July 2018 & 2,330 & June 2019 & 3,360 \\
\hline August 2018 & 2,360 & July 2019 & 3,200 \\
\hline September 2018 & 2,550 & August 2019 & 3,060 \\
\hline October 2018 & 2,450 & September 2019 & 2,900 \\
\hline November 2018 & 2,500 & October 2019 & 2,770 \\
\hline December 2018 & 2,600 & November 2019 & 1,735 \\
\hline January 2019 & 2,950 & December 2019 & 1,250 \\
\hline February 2019 & 3,190 & January 2020 & 1,000 \\
\hline Source: idx.coid & & &
\end{tabular}

Source: idx.co.id

Stock price movements of PT. Kimia Farma, before the acquisition, had the lowest share price in June 2018 at Rp. 2,330 and the highest share price in February 2019 at Rp. 3,190. While the movement of the stock price of PT. Kimia Farma, after the acquisition, had the lowest share price in January 2020 at Rp. 1,000 and the highest share price in May 2019 at Rp. 3390.

PT. Kimia Farma Tbk. before making the acquisition (May 2018-February 2019) tended to increase every month, while the share price of PT. After the acquisition (April 2019-January 2020), Kimia Farma experienced a drastic decline, which was initially Rp. 3,000 per share to Rp. 1,000 per share.

\section{Signalling Theory}

Signalling theory is data signs to consider whether financial backers will put their portions in the organization concerned. Signalling theory guides financial backers on the best way to 
evaluate the organization's possibilities and the moves to be made by the administration of an organization (Ehrhardt, 2005).

Great quality organizations will give market signals as data. Consequently, the market can recognize great and terrible quality organizations. Signs that are supposed to be viable are signals that low-quality organizations do not handily imitate, can be seen well, and can be caught by the market (Megginson, 1997) (Candra, 2019).

Jogiyanto (2013) in (Candra, 2019) states that positive or negative data settling on venture choices is educated through distributed declarations. On the off chance that the declaration of the data contains a worth that financial backers don't yet know, the data will be investigated, so it very well may be presumed that the data is a positive or negative sign. Then again, if the data gives a decent sign, it is normal that the market will respond at the hour of the declaration with changes in the cost and level of stock deals.

The organization took the choice (obtaining) will give a sign to the market as data that can influence the organization's worth. Concerning market members, a choice taken by an organization has a valuable worth that will be utilized as thought before settling on a venture choice. Market members initially decipher and dissect the data distributed by the organization as a decent sign (uplifting news) or an awful sign (awful news). Moreover, the data that was spread and reported welcomed a few responses on the lookout. This response can be seen from the development of stock prices (Nurussobakh, 2016).

(Connelly et al., 2011) states that data can influence the dynamic interaction that somebody will do. The presence of the conveyance of data can make somebody change their conduct. Financial backers require complete, applicable, precise, and convenient data. The data gives a few clarifications and portrayals in the capital market that can be utilized as a logical apparatus to settle on venture choices.

\section{Event Study}

An event study or event study in the capital market sector is an analysis of the impact of an event on the capital market, which is carried out by the empirical study. In other words, this study was conducted to see the capital market's reaction to an event. In capital market research, especially market efficiency testing, event study is used to test market efficiency semi-strong form (Suganda, 2018).

An event study is a study that observes the impact of information announcements on security prices. Research is an Event study generally concerned with how quickly the information that enters the market can be reflected in stock prices (Tandelilin, 2010). The trigger event is the acquisition by PT. Kimia Farma Tbk. against PT. Phapros Tbk described in Figure 1.1

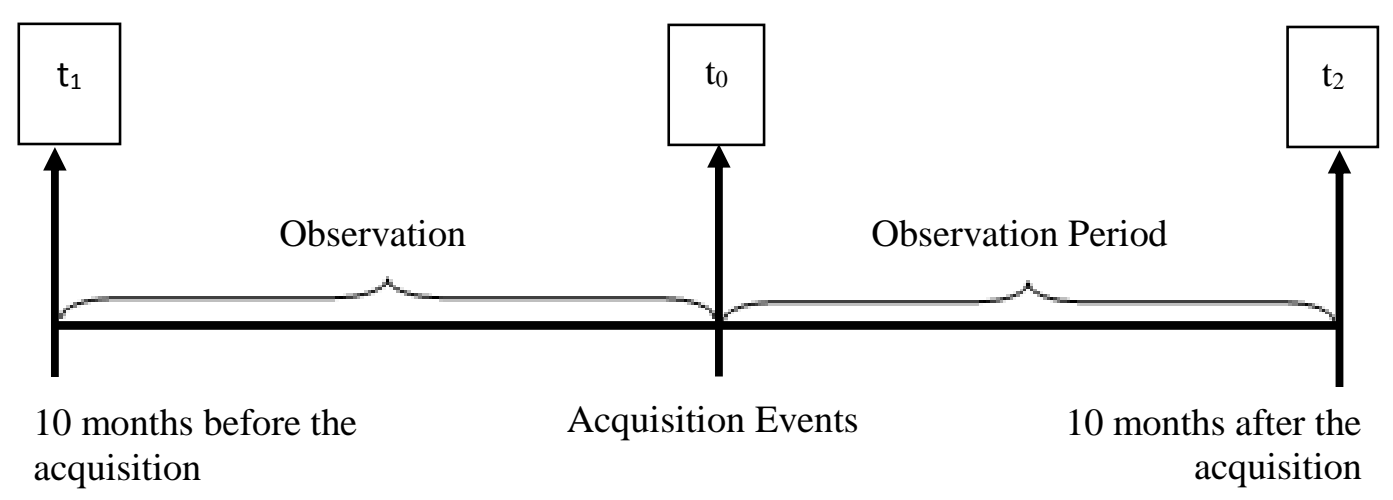

Figure. 1. Estimated period and window period for an observation period 


\section{Acquisition}

The acquisition is derived from acquisition (Latin) and acquisition (English). The meaning of acquisition is to buy or get something/object to add to something/object that has been previously owned. According to the definition of acquisition according to Article 1 point 11 of the Company Law, the acquisition or takeover can be interpreted as a legal action carried out by a legal entity or individual to take over the shares of the Company which results in the transfer of control over the Company(Tarigan et al., 2017).

Republik Indonesian unofficial law no. 27 of 1998 concerning the consolidation, combination, and takeover of regional responsibility organizations characterizes that procurement as a lawful activity completed by a legitimate substance or individual to assume control over all or a significant portion of the organization's portions which can bring about the exchange of power over the organization. Bookkeeping point of view on acquisitions in PSAK No. 22 section 03 clarifies that procurement is an exchange or other occasion wherein the acquirer gets control of at least one organization (IAI, 2019).

Acquisition Method According to PSAK No. 22 paragraph 04, describing the application of the acquisition method requires:

a) Identification of the acquirer;

b) Determination of acquisition date;

c) Recognition and measurement of identifiable assets acquired, liabilities assumed, and noncontrolling interests of the acquiree; and

d) Recognition and measurement of goodwill or gain from discounted purchases (IAI, 2019).

Acquisitions depend on two intentions that urge an organization to direct consolidations and acquisitions, particularly financial thought processes and non-monetary intentions. The financial thought process is identified with the pith of the organization's objective, to be specific to expand the organisation's worth or amplify the flourishing of investors. Then again, non-financial thought processes are intentions that are not founded on the emotional longings or individual aspirations of the proprietors or the executives of the organization. Comprehensively talking, the intentions in consolidations and acquisitions are as per the following (Moin, 2010):

e) Economic Motives The

The cooperative energy thought process is one of the primary purposes behind purchasers purchasing at a more exorbitant cost, past the organisation's genuine worth of the organization of interest. Collaboration alludes to the response caused when two organizations are consolidated to create a vastly improved result for the two elements worried than each organization working autonomously. This wonder is regularly depicted as $2+2=5$. With regards to consolidation, this is deciphered as the capacity of at least two organizations joined to produce more substantial benefits than if the organizations worked autonomously (Gaughan, 2010). Gaughan stressed that there are two kinds of collaborations: functional cooperative energies and cooperative monetary energies. Functional cooperative energy alludes to two structures, to be specific, income upgrade and cost decrease. Monetary cooperative energy alludes to the likelihood to get a lower cost of capital from the consolidation of at least two organizations.

The intention of broadening is a business enhancement methodology that should be possible through consolidations and acquisitions. Expansion is planned to help the organization's business exercises and tasks to get a serious position and diminish the danger of reliance on one-centre business. The organization differentiates its business through the procurement of different organizations to diminish the unpredictability of money receipts and benefits. 
Non-Economic Motives The procurement thought process isn't just founded on financial contemplations however can be founded on different contemplations like distinction and aspiration. Non-financial intentions come from individual interests (individual interest thought processes) both from the board and friends proprietors.

\section{Shares}

Shares are protections that turn out revenue as profits, particularly the circulation of benefits conveyed to investors (financial backers). Susilo (Hermuningsih, 2012) indicated that shares indicate an individual's capital investment or a party (business substance) in an organization or restricted obligation organization. An organization can sell its possession freedoms as (stock). On the off chance that the organization just issues just one class of stock, this stock is called normal stock.

To draw in other likely financial backers, the organization may likewise give classes other than shares, called shares liked (favoured stock). The favoured stock has to need freedoms over shares typical. The need privileges of favoured stock are freedoms to fixed profits and freedoms to resources in liquidation (Hartono, 2010).

\section{Book Value}

Value Equity value is a non-summing convex function of expected profit, and book value depends on its relative value. This book value can lead to an adaptation value that reflects the company's net resource value in subsequent alternative uses (Linda \& BZ, 2005).

Book esteem is the worth of offers indicated by the backer's books, market esteem is the book worth of offers in the financial exchange, and natural worth is the actual worth of offers. One methodology in deciding the characteristic worth of a stock is the value book esteem. Value book esteem is one of the valuation proportions, in particular. This proportion gives a proportion of the executives' capacity to make the market an incentive for its business above speculation costs by contrasting the financial exchange esteem with book esteem, where the higher the PBV proportion implies, the more fruitful the organization is in making an incentive for investors, which will likewise affect firm worth (Danil \& Yusra, 2019). Book value per share is the amount of rupiah that belongs to each share in the company's capital. Book value can be calculated with the following formula:

$$
\text { Book Value = Total Equity } / \text { Number of Outstanding Shares .............1) }
$$

\section{Market Value}

Market esteem is the impression of the market that comes from financial backers, loan bosses, and different partners to the state of the organization and is usually reflected in the market worth of the organization's stock. Market esteem is the general worth of offers possessed by an organization. All in all, market esteem is the sum that should be paid to purchase the organization overall. The ascent and fall of an organization's reasonably estimated worth are impacted by the organization's book esteem, benefit level, financial picture, just as theory and trust in the organization's capacity to make esteem. In contrast, the book esteem is the worth of the organization's riches, obligation, and value dependent on authentic records and is typically recorded on the accounting report. In any case, the book esteem is not the same as the organisation's aggregate sum of resources and liabilities. Assuming the organization sells every one of its resources and pays every one of its liabilities, the distinction from that sum is the book worth of the organization (Chen et al., 2005). 
Market value is the actual price that is easiest to determine because it is the price when the market is ongoing or when the market is closed. The market price is the closing price (closing price) listed on OTC (Over the Counter Market) and the primary exchange. The market price was the selling price from one investor to another and referred to as the secondary market price. The UPS and downs of stock and is announced every day in newspapers or other media. The market value can be calculated by multiplying the stock market price by the total outstanding shares (Anoraga, 2006).

$$
\text { Market Value }=\text { Number of Shares Outstanding X Closing Market Price ...........2) }
$$

\section{Intrinsic Value}

Mardiyanto (2009) states that a product's natural worth or reasonable worth is the current worth of a progression of money inflows created later on. The worth (or the current worth of money inflows) of an item is dictated by a blend of three components: danger, return, and time. The characteristic worth of a stock is the real or assumed worth of the stock. Inborn worth is the genuine worth of the stock. Inborn worth (NI) is the current worth of the ordinary income of the stock. The rules utilized are as per the following:

a. On the off chance that NI > current market value, the stock is considered underestimated. (the cost is excessively low), and in this way ought to be purchased or held when the offers are possessed.

b. On the off chance that NI < current market value, the stock is considered exaggerated (the cost is excessively costly) and in this manner ought to be sold.

c. Assuming NI = current market value, the stock is viewed as reasonable in cost and is in a condition of equilibrium.

Natural worth was the organisation's fundamental or genuine worth when the organization was not gained or when it was all the while standing independently under the old administration. The intermediary used to quantify the natural worth is the Price Earning Ratio (PER). PER is a correlation between the stock cost and the profit of an organization. PER shows how far financial backers will pay per unit of cash from revealed benefits. PER shows the cost of every rupiah profit organization. Likewise, PER is additionally a proportion of the overall cost of an organization's portions (Hayati, 2010). PER is comparing the price of a stock with net income for each share (Earning Per Share) of the company.

$$
\text { PER = Share Price } / \text { Earning Per Share ................3) }
$$

\section{Hypothesis}

Acquisition business terminology is the takeover of ownership or control over shares or assets of a company by another company. In this event, either the takeover company or the acquired company still exists as a separate legal entity (Moin, 2010). From a financial perspective (Jensen, 2005), asset restructuring through acquisitions can increase the company's competitiveness, the occurrence of corporate control and ultimately benefit shareholders, society, and the company. Sanders (2019) provides empirical evidence that the effect of the acquisition on the value of the company's shareholders. Merger and acquisition activities can provide economic benefits in the market. The hypotheses used in this study are:

$\mathrm{H}_{0}$ : There is no significant difference in book value, market value, and intrinsic value of PT Kimia Farma shares between before and after the acquisition 
$\mathrm{H}_{\mathrm{a}}$ : There are significant differences in book value, market value, and intrinsic value of PT Kimia Farma between before and after the acquisition

\section{RESEARCH METHOD}

This research is a comparative study with a quantitative descriptive approach by comparing the stock value of PT. Farm Chemistry a Tbk. Before and after the acquisition. The data source in this study is the Indonesia Stock Exchange (www.idx.co.id, 2020). The data in this study is secondary data in the form of the Financial Statements of PT. Kimia Farma Tbk. Accessed through the Indonesia Stock Exchange for ten months (May 2018-February 2019) before the acquisition and ten months (April 2019-January 2020) after the acquisition of PT. Phapros Tbk by PT. Kimia Farma Tbk. The data used in the study are tabulated in the table below.

Table 2. Book Value, Market Value and Intrinsic Value (PER) PT. Kimia Farma Tbk During the Observation Period

\begin{tabular}{ccccc}
\hline Period & Month & Book Value & Market Value & PER \\
\hline $\mathbf{1}$ & May 2018 & 463 & 14.107 .160 .000 .000 & 379 \\
\hline $\mathbf{1}$ & June 2018 & 481 & 13.107 .440 .000 .000 & 107 \\
\hline $\mathbf{1}$ & July 2018 & 481 & 12.940 .820 .000 .000 & 106 \\
\hline $\mathbf{1}$ & August 2018 & 481 & 13.107 .440 .000 .000 & 107 \\
\hline $\mathbf{1}$ & September 2018 & 501 & 14.162 .700 .000 .000 & 63 \\
\hline $\mathbf{1}$ & October 2018 & 501 & 13.607 .300 .000 .000 & 60 \\
\hline $\mathbf{1}$ & November 2018 & 501 & 13.885 .000 .000 .000 & 62 \\
\hline $\mathbf{1}$ & December 2018 & 604 & 14.440 .400 .000 .000 & 35 \\
\hline $\mathbf{1}$ & January 2019 & 604 & 16.384 .300 .000 .000 & 39 \\
\hline $\mathbf{2}$ & February 2019 & 604 & 17.717 .260 .000 .000 & 43 \\
\hline $\mathbf{2}$ & April 2019 & 489 & 16.662 .000 .000 .000 & 809 \\
\hline $\mathbf{2}$ & May 2019 & 489 & 18.828 .060 .000 .000 & 914 \\
\hline $\mathbf{2}$ & June 2019 & 1.420 & 18.661 .440 .000 .000 & 391 \\
\hline $\mathbf{2}$ & July 2019 & 1.420 & 17.772 .800 .000 .000 & 372 \\
\hline $\mathbf{2}$ & Augusts 2019 & 1.420 & 16.995 .240 .000 .000 & 356 \\
\hline $\mathbf{2}$ & September 2019 & 1.424 & 16.106 .600 .000 .000 & 385 \\
\hline $\mathbf{2}$ & October 2019 & 1.424 & 15.384 .580 .000 .000 & 368 \\
\hline $\mathbf{2}$ & November 2019 & 1.424 & 9.636 .190 .000 .000 & 230 \\
\hline $\mathbf{2}$ & December 2019 & 1.335 & 6.942 .500 .000 .000 & -546 \\
\hline $\mathbf{1}$ Period= before acquisition & 1.335 & 5.554 .000 .000 .000 & -437 \\
\hline $\mathbf{P}$ Period= after the acquisition & & & \\
\hline & & & &
\end{tabular}

\section{Data Analysis Techniques}

\section{Descriptive StatisticalDescriptive}

statistics include collecting, processing, and presenting data. The presentation can use tables, diagrams, sizes, and pictures. Descriptive statistics are indicated by frequency, dispersion (standard deviation, variance, and range), measures of central tendency (mean, mode and median) (Hendrayadi \& Suryani, 2015).

\section{Hypothesis Testing Hypothesis}

Testing using a non-parametric test using the Wilcoxon signed-rank test is used to test the hypothesis that two variables, two related samples, have the same distribution if the data is in ordinal form. This test is a refinement of the sign test. This test tests $\mathrm{Ha}_{1}-\mathrm{Ha}_{3}$, using a significant level $=5 \%$, so if the probability $<$ the predetermined significance level $=5 \%$, then the independent variable has a significant effect on the dependent variable, meaning that there 
is a statistically significant difference for each. The stock value between before and after the acquisition (Ghozali, 2013).

\section{RESULTS AND DISCUSSION}

\section{Descriptive Statistics}

Researchers use analysis frequencies in descriptive statistical methods because using descriptive statistical method analysis is very useful to obtain a summary of an individual variable to provide an overview of the average value, the highest data value. As well as the highest and lowest values of the variables of book value, market value, and intrinsic value for 10 months before and after the acquisition.

Table 3. Descriptive Statistics Analysis of Frequencies

\begin{tabular}{lcccc}
\hline Variables & $\mathrm{N}$ & Min & Max & Mean \\
\hline Book Value Before Acquisition & 10 & 463 & 604 & 522.1 \\
\hline Book Value After Acquisition & 10 & 489 & 1424 & 1218 \\
\hline Market Value-Before Acquisition & 10 & $12.900^{*}$ & $17.700^{*}$ & $14.300^{*}$ \\
\hline Market Value After Acquisition & 10 & $5.550^{*}$ & $18.800^{*}$ & $14.300^{*}$ \\
\hline PER Before Acquisition & 10 & 35 & 379 & 100.1 \\
\hline PER After Acquisition & 10 & -546 & 914 & 284.2 \\
\hline
\end{tabular}

Notes: *in Billion

The average book value of shares increased after the acquisition, the average market value remained after the acquisition, and the average market value also increased after making the acquisition. The minimum value for book value increases after the acquisition, while the intrinsic value and market value decreases after the acquisition. The maximum book value, intrinsic value of shares, and market value increased after the acquisition.

\section{Hypothesis Testing}

\section{Wilcoxon Signed-Rank Test}

Based on the results of data processing with the Wilcoxon Signed Rank Test, which was carried out using the IBM SPPS version 19 application, the empirical facts were obtained, which are explained below:

1) Variable Book Value

Table.4 Test Results Wilcoxon Signed Rank Test Book Value of PT. Kimia Farma Tbk.

\begin{tabular}{lr}
\hline & $\begin{array}{r}\text { Book Value After Acquisition-Book Value Before } \\
\text { Acquisition }\end{array}$ \\
\hline $\mathrm{Z}$ & $-2.809^{\mathrm{b}}$ \\
\hline Asymp. Sig. (2-tailed) &, 005 \\
\hline
\end{tabular}

The book value of shares is the (net assets) owned by shareholders by owning one share value of shares of PT. Kimia Farma Tbk due to the total equity of PT. Kimia Farma Tbk. Increased significantly after the acquisition of PT. Phapros Tbk. The addition of total equity is because of PT. Kimia Farma added a capital structure consisting of the company's internal cash and bridging loans from third parties (national and state-owned banks) with a share of e. Since net assets are equal to total shareholders' equity, the book value per share is total equity divided by the number of shares outstanding (Mufidah, 2017). 
2) Variable Market Value

Significance value (2-tailed) is the market value of PT. Kimia Farma Tbk. showed a sig(2tailed) result of 0.575 ( $>0.05$ level of significance). Then $\mathrm{H}_{0}$ is accepted, and $\mathrm{H}_{1}$ is rejected (there is no significant difference between the stock value of PT. Kimia Farma Tbk. before and after the acquisition).

Table. 5 Test Results Wilcoxon Signed Rank TestMarket Value Share of PT. Kimia Farma Tbk.

\begin{tabular}{lr}
\hline & $\begin{array}{r}\text { After Market Value Acquisition - Market Value-Before the } \\
\text { acquisition of }\end{array}$ \\
\hline $\mathrm{Z}$ &,$- 561^{\mathrm{b}}$ \\
\hline Asymp. Sig. (2-tailed) &, 575 \\
\hline
\end{tabular}

Market Value indicates the share of a company's profits, dividends, and capital distributed to each share. Leverage is used to measure a company's stock market price relative to its book value (Hartono, 2010). It was concluded that after PT. Kimia Farma Tbk. Make the acquisition. There is no significant difference in the market value of the shares of PT. Kimia Farma Tbk. There is no significant difference in the stock market value of PT. Kimia Farma Tbk.

3) Variable Intrinsic Value

The value of sig(2-tailed) is the intrinsic value of PT. Kimia Farma Tbk. showed a sig(2tailed) result of 0.203 (> 0.05 level of significance). So that $\mathrm{H}_{0}$ is received and $\mathrm{H}_{1}$ rejected (not a significant difference between the intrinsic value of the shares of PT. Kimia Farma Tbk, before and after the acquisition).

Table. 6 Test Results Wilcoxon Signed Rank Test Intrinsic Market Value PT. Kimia Farma Tbk.

\begin{tabular}{lr}
\hline & PER After Acquisition - PER Before Acquisition \\
\hline $\mathrm{Z}$ & $-1.274^{\mathrm{b}}$ \\
\hline Asymp. Sig. (2-tailed) &, 203 \\
\hline
\end{tabular}

Intrinsic value is the actual value of the stock being traded, and Intrinsic value does not necessarily affect the formation of a reasonable stock market price. A stock valuation is a prediction to know the intrinsic value as the starting point for choosing which stock to invest in and finding out if the intrinsic value already reflects the stock's market price. An efficient market can be said if the price of a security does not deviate from its intrinsic value. An intrinsic value is essential for measuring a stock whether the stock price is too low, reasonable, or overvalued (Sitorus \& Hutasoid, 2019).

It was concluded that after PT. Kimia Farma Tbk. Make the acquisition there is a significant difference to the book value of shares of PT. Kimia Farma Tbk. The occurrence of a significant difference in the variable book $30 \%$ and $70 \%$ to buy shares of PT. Phapros Tbk, besides that, this corporate action also provides positive sentiment for PT. Phapros Tbk increases the value of shares which automatically increases the book value of shares of PT. Kimia Farma Tbk. The acquisition has not succeeded in increasing the sales and market expansion of PT. Kimia Farma Tbk. Corporate action (acquisition) carried out by PT. Kimia Farma Tbk has not been able to provide a positive sentiment on the value of its shares. The post-acquisition stock price was corrected negatively with a significant price decline, although on the other hand, PT. Phapros Tbk, as a subsidiary company, received positive sentiment in the capital market because of the correction in its share price.

The intrinsic value that does not change after the acquisition process is because of PT. Phapros, Tbk. as a subsidiary has not contributed significantly to PT. Kimia Farma, Tbk., as the 
holding company. The results of the acquisition appear to be able to increase the company's net profit, but experience a decrease in annual profits which has an impact on the company not being able to maximize its profit investment to then earn profits and increase the intrinsic value of its shares (www.cnbc.com, 2019). Profit PT. Phapros Tbk, after the acquisition process, experienced a very significant decrease, namely by $23 \%$ from the same period in the previous year, so that the corporate action has not had an impact on the value.

\section{CONCLUSION}

The value of pt. Kimia Farma Tbk, judging from the variable book value, there is a significant difference in the book value of shares of PT. Kimia Farma Tbk. Before and after the acquisition of PT. Phapros. Tbk by PT. Kimia Farma Tbk. Concluded that the book value of shares of PT. Kimia Farma increased significantly after acquiring PT. Phapros Tbk due to changes in the corporate capital structure. The test results use variable market value and intrinsic value of PT. Kimia Farma Tbk, there was no significant difference before and after the acquisition of PT. Phapros Tbk by PT. Kimia Farma Tbk. Concluded that after the acquisition of PT. Phapros by PT. Farma chemistry has not had an impact on the market value and intrinsic value of corporate stocks.

\section{REFERENCES}

Anoraga. (2006). Pengantar Pasar Modal, Cetakan ke IV (Edisi Revi). Jakarta: PT Rineka Cipta.

As'ari, H., Ahmad Pabulo, A. M., \& Zaman, B. (2019). Pengaruh Restrukturisasi Perusahaan Terhadap Kinerja Perusahaan. Jae (Jurnal Akuntansi Dan Ekonomi), 4(3), 10-21. https://doi.org/10.29407/jae.v4i3.13133.

Candra, R. (2019). Pengaruh Debt To Equity Ratio, Return On Asset Terhadap Return Saham Perusahaan Makanan dan Minuman Indonesia. Jurnal Fairness, 9(7), 245-254.

Chen, M., Cheng, S., \& Hwang, Y. (2005). An empirical investigation of the relationship between intellectual capital and firms' market value and financial performance. Journal of Intellectual Capital, 6(2), 159-176. https://doi.org/10.1108/14691930510592771.

Connelly, B. L., Certo, S. T., Ireland, R. D., \& Reutzel, C. R. (2011). Signaling Theory: A Review and Assessment. Journal of Management, 37(1), 39-67. https://doi.org/10.1177/0149206310388419

Danil, A., \& Yusra, I. (2019). Pengaruh Kausal Antara Ukuran Perusahaan, Nilai Buku Dan Likuiditas Saham Di Bursa Efek Indonesia. https://doi.org/10.31227/osf.io/ruhc5

Ehrhardt, B. . (2005). Dasar-Dasar Manajemen Keuangan. Jakarta: Salemba Empat.

Fuad, M., \& Dkk. (2006). Pengantar Bisnis (Cet.5). Jakarta: PT Gramedia Pustaka Utama.

Gaughan, P. A. (2010). Mergers, Acquisitions, and Corporate Restructurings. New Jersey: 
John Wiley \& Sons, Inc. https://doi.org/10.1002/9781118269077.

Ghozali, I. (2013). Aplikasi Analisis Multivariate Dengan Program IBM dan SPSS. In aplikasi analisis multivariate dengan program ibm spss 19 (Edisi ke-7). Semarang: Badan Penerbit Universitas Diponegoro.

Hartono, J. (2010). Teori Portofolio dan Analisis Investasi (Edisi Sepuluh). Yogyakarta: BPFE.

Hayati, N. (2010). Studi Kelayakan Pendirian Bank Perkreditan Rakyat di Kabupaten Tanah Bumbu Ditinjau Dari Aspek Keuangan. Jurnal Manajemen Dan Akuntansi, 11(1), 53-62.

Hazelkorn, T., Zenner, M., \& Shivdasani, A. (2004). CREATING VALUE WITH MERGERS AND ACQUISITIONS. Journal of Applied Corporate Finance, 16(2-3), 81-90. https://doi.org/10.1111/j.1745-6622.2004.tb00540.x

Hendrayadi, \& Suryani. (2015). Metode Riset Kuantitatif: Teori dan Aplikasi pada Penelitian Bidang Manajemen dan Ekonomi Islam (Ed. 1; Cet). Kencana Prenada Media.

Hermuningsih, S. (2012). Pengantar Pasar Modal Indonesia (Edisi 2). Yogyakarta: UPP STIM YKPN.

Jensen, M. C. (2005). Takeovers: Their Causes and Consequences. SSRN Electronic Journal, 2(1), 21-48. https://doi.org/10.2139/ssrn.173455

Liliana, Suhadak, \& Hidayat, R. R. (2016). Analisis Dampak Akusisi Terhadap Return Saham dan Volume Perdagangan (Studi pada Multinational Company yang Terdaftar di BEI Periode Tahun 2010-2012). Jurnal Administrasi Bisnis.

Linda, \& BZ, F. S. (2005). Hubungan Laba Akuntansi, Nilai Buku Ekuitas dan Total Arus Kas dengan Market Value: Studi Akuntansi Relevansi Nilai. Jurnal Riset Akuntansi Indonesia, Vol 8 .

Mardiyanto, H. (2009). Inti Sari Manajemen Keuangan: Teori, Soal dan Jawaban (1st ed.). Jakarta: Grasindo.

Moin, A. (2010). Merger, Akuisisi dan Divestasi. Yogyakarta: Ekononesia.

Mufidah, E. (2017). Analisis Laba, Arus Kas Operasi Dan Nilai Buku Ekuitas Terhadap Harga Saham. Eksis: Jurnal Riset Ekonomi Dan Bisnis, 12(1). https://doi.org/10.26533/eksis.v12i1.79

Nurussobakh. (2016). Perbedaan Actual Return, Abnormal Return, Trading Volume Activity, Dan Security Return Variability Saham Sebelum dan Setelah Merger. Jurnal Keuangan Dan Perbankan, 13(1), 62-77.

Sanders, S. (2019). Firm mergers and acquisitions (M\&As). Managerial Finance, 45(10-11), 1349-1353. https://doi.org/10.1108/MF-10-2019-636.

Shleifer, A., \& Vishny, R. W. (2003). Stock market driven acquisitions. Journal of Financial Economics, 70(3), 295-311. https://doi.org/10.1016/S0304-405X(03)00211-3. 
SHARE VALUE DIFFERENCES PT. KIMIA FARMA TBK TOWARDS THE ACQUISITION OF SHARE EVENTS in PT. PHAPROS TBK

Revi Candra, Elmiliyani Wahyuni S, and Nailatul Hanifah

Sitorus, F. Y., \& Hutasoid, P. S. J. K. (2019). Pengaruh EPS dan Return Saham terhadap IHSG BEI menggunakan Value Investing dari Benjamin Graham. Fundamental Management Journal, 2(1), 16-21. http://ejournal.uki.ac.id/index.php/jm/article/view/426

Suganda, T. R. (2018). Event Study, Teori dan Pembahasan Reaksi Pasar Modal Indonesia 1st ed. Jakarta: CV. Seribu Bintang. https://doi.org/10.31227/osf.io/zbqm7

Tandelilin, E. (2010). Portofolio dan Investasi Teori dan Aplikasi. Yogyakarta: KANISIUS.

Tarigan, J., Yenewan, S., \& Natalia, G. (2017). Merger dan Akuisisi: dari Prespektif Strategis dan Kondisi Indonesia (Pendekatan Konsep dan Studi Kasus). Jurnal Merger Dan Akuisiss, $1(6), 39-59$.

Yuliana, I. (2010). Investasi Produk Keuangan Syariah. In Malang: UIN-Press.

Zulfikar. (2016). Pengantar Pasar Modal dengan Pendekatan Statistika. Edisi 1. Yogyakarta: Deepublish. 